\title{
Indigenous Feminism and Black Women Leadership
}

\author{
Vuyisile Msila
}

College of Education (CEDU), University of South Africa, South Africa

Received August 9, 2021; Revised December 23, 2021; Accepted December 29, 2021

\begin{abstract}
Cite This Paper in the following Citation Styles
(a): [1] Vuyisile Msila, "Indigenous Feminism and Black Women Leadership," Sociology and Anthropology, Vol. 9, No. 4, pp. 42 - 51, 2021. DOI: 10.13189/sa.2021.090402.
\end{abstract}

(b): Vuyisile Msila (2021). Indigenous Feminism and Black Women Leadership. Sociology and Anthropology, 9(4), 42 51. DOI: 10.13189/sa.2021.090402.

Copyright $@ 2021$ by authors, all rights reserved. Authors agree that this article remains permanently open access under the terms of the Creative Commons Attribution License 4.0 International License

\begin{abstract}
For decades, feminism has been a concept associated with women's freedom from patriarchy, and this movement started in 1848 in Europe. Several political and social movements have fought on the side of women for gender equality over decades. In the 1960s, radical feminism grew because of the women's liberation movement, which continued well into the 1970s and 1980s. Over the years, feminism has given a voice to women wanting to unshackle themselves from patriarchy. This conceptual article examines indigenous feminism, which is an alternative to Eurocentric feminism. Amongst others, the indigenous feminists perceive their mandate as one of decolonizing feminism, thus looking beyond patriarchy as the sole problem women face in society. Indigenous feminists also recognize race, class and colonial history as among the major obstacles to women's advancement. Using theory synthesis, the article found that indigenous feminism embraced by womanism reflects how African women could contest for social justice and equality while utilizing certain values and principles. The conclusions demonstrate that women from the Global South will be empowered by African philosophies as they become strong leaders in society. Furthermore, the conclusions point out that empowered African women would be able to confront social injustices that stunt their growth as leaders in society.
\end{abstract}

Keywords Africana Womanism, Decolonization, Indigenous Feminism, Motherism, Ubuntu, Woman Leadership

\section{Introduction and Background}

Recently, writers have written about the invisibility of women in positions of power, citing barriers that women leaders face relative to their contexts [1], [2], [3]. In trying to understand this invisibility, African societies frequently use Eurocentric feminist theories instead of African epistemologies [4]. Several African activists have found gender in Africa a colonial project where Western experts tend to generalize across cultures as they misrepresent and marginalize certain values when it comes to the portrayal of black women in society [5], [6], [7], [8]. Lewis [9] argues that the mass media portray twisted images of women; they are sex objects, vulnerable and deficient. Additionally, the media keep women down, as they become "images of old, fixed ideas about femininity and masculinity" [8]. Phakeng [1] underscores the invisibility of black women in South Africa and how they witness the masculinity of power. Furthermore, Phakeng [1] argues that despite the attainment of democracy, there are very few black South African women in positions of power. "Since black African women are almost entirely invisible, the possibilities of becoming, and then being visible are an enormous challenge" [1]. Poltera [3] contends that African societies need to address this invisibility. According to Poltera [3] society should also identify and redress long standing gender inequality, inequity, oppression, power imbalances, as well as patriarchal norms. Lues [10] traces the sluggish evolution of black women in South Africa by moving from the premise that, like in various places around the world, black women have been oppressed for decades as they have been marginalized by their societies. 
The transformation of the workplace in South Africa was the transformation that sought to address class, race and gender [11]. Mayer also cites Badat who cautions that transformation of workplaces will be hollow if it does not address elements such as deracialization, decolonization, de-gendering and demascularization. Much of the research done in the area of gender frequently utilizes the intersectional theory perspective. This theory includes the intersecting of social identities such as race, gender, age and sexuality which are also intertwined with other systems of oppression and domination.

In her insightful and thought-provoking paper on West African societies, Oyewumi [5] argues that the concept of 'gender' is a result of Western imperialism, and she contends that this concept for her traditional Yoruba in Nigeria was imported from Europe hence it is alien to Africa. Moreover, Lugones [12] points out, "Oyewumi understands gender as introduced by the West as a tool of domination that designates two binaries opposed and hierarchical social categories. Women (the gender term) are not defined by biology, though it is assigned to anafemales. Women are defined in relation to men; the norm [...] none of this was true of Yoruba anafemales prior to colonization." Oyewumi explains that the anamale and the anafemale are anatomical males and females who have no hierarchical connotations. The two defy the Western dichotomy where one is dominant over the other. Furthermore, seniority in the Yoruba culture determined social power and not gender. To avoid using the western conceptions of feminism, progressive feminists prefer the term indigenous feminism or womanism to demonstrate that the western notions of feminism are not universal. It is unfortunate that Western feminists seek to define the cause of all feminists and this leads to misrepresentation [9].

Indigenous feminism is referred to as an intersectional theory of feminism that underscores decolonization, indigenous sovereignty and human rights for indigenous women and their families [13]. Many have compared this to womanism in African American communities and womanism refers to a social theory based on the history of black women. The concept sometimes combines contradictory conceptions such as feminism, men and blackness [14]. Although womanism started in North America, Canada and Australia among the indigenous people or First Nations, womanists see no link between themselves and feminists [6], [15]. The problem with early feminism is that it did not regard black women as feminine [9]. White feminists excluded black women in America and they only focused on gender rather than on other struggles of blackness [16]. Womanism was borne out of activism by black women who realized how ostracized they were by white feminists and hence they found no connection between womanism and feminism. It is also a theory that black women seek to demonstrate culture and alternative ways of understanding femininity [9], [16].
This conceptual article explores three aspects; firstly, it focuses on the debates used by feminists and how they exclude and alienate African women. Secondly, it examines how African women can rethink leadership strategies to reclaim self-determination, rights and liberation. Finally, the article investigates ways in which society and African women can enhance their leadership capabilities.

\section{Definition of Terms}

The following concepts are used widely in literature globally and may be understood in different ways. Their inclusion in the list below is to clarify how they should be understood in this article.

Feminism - Feminism refers to the advocacy of women's rights and the emphasis is on fighting sexism in society. It refers to a belief in and advocacy of equal rights for women based on the idea of the equality of sexes [17]. Her seminal book, The Second Sex, [16] demonstrates how the male is the default and the woman the other. Feminism, according to Beauvoir, is the women's struggle against male oppression for women, which is always defined in relation to men. Women need to fight for their freedom in the world as they transcend patriarchal domination. Much literature today sees feminism as being too Western and white because it tends to exclude the black women. The latter is the reason many progressive African activists are opposed to the use of the concept and prefer the use of womanism.

Indigenous Feminism - This is a kind of feminism that underscores decolonization, indigenous sovereignty, social justice and human rights for all indigenous women and their families [19]. Smith [13] states that indigenous feminism acknowledges the destructive nature of colonization on indigenous people and the importance of decolonization to dismantle oppressive systems. Using this concept in this article, we will be mindful of Moreton-Robenson's [20] declaration. Moreton-Robenson [20] emphasizes the need to distinguish indigenous feminism from what she calls white feminism as explained above; she claims that this is crucial because indigenous women have different experiences from those of non-indigenous women.

Motherism - This is said to be the Afrocentric alternative to feminism [21]. Alkali, Talif, Yahya and Jan [22] cite Acholonu who points out that the women's freedom is through Motherism because it is impossible to cut the issues of motherhood from the African women. Furthermore, this African feminism considers nature, nurture and respect in the mother-child area as the core of any motherist debate [22].

Womanism - This refers to the viewpoint of black women, which is different from the white women's standpoint on feminism explicated above [22]. Furthermore, Alkali et al. [22] point out, "The noticeable 
contention has been that some womanists have observed the negative and perhaps, unintended consequences of Western feminism on -women of colour. White feminists have apparently paid no attention to and silenced the black communities." Some researchers have come up with a concept close to womanism and this is STIWANISM learners, which stands for, Social Transformation Including Women in Africa. STIWANISM reflects feminism in an African context [23].

\section{Methodology}

In this article I use one of Jaakkola's [24] approaches to presenting conceptual papers. Jaakkola [24] lists four potential templates for conceptual papers and these are theory synthesis, theory adaptation, typology and model. However, for the purposes of this analysis I use theory synthesis. A strong conceptual paper should not be devoid of the rigor of analysis and research. The theory synthesis employed will help me ensure that the research design addresses the problem. Jaakola [24] points out that a theory of synthesis wants to integrate several theories and literature streams. Integration helps researchers to perceive a phenomenon in a new way by transforming past findings into a new higher-order level [24]. Furthermore, Jaakkola [24] cites Delbridge and Fiss who posit that the synthesis paper represents theorizing that underscores narrative reasoning that wants to achieve the unveiling of a big picture, patterns and correctness rather than causal mechanisms. Pound and Campbell [25] point out that synthesis follows three stages:

(i) synthesis preparation - (parts of several theories summarized);

(ii) synthesis which involves comparing theories to establish points of convergence and divergence;

(iii) synthesis refinement where synthesis is examined for theoretical insights.

Like Pound and Campbell, McCombes [26] highlights four steps to synthesize information from various sources and these are:

(i) organizing your sources

(ii) outline your structure

(iii) write paragraphs with topic sentences

(iv) revise, edit and proofread.

These steps were vital in synthesising information when this article was written. Generally, synthesis methodology encompasses approaches that seek to combine, integrate and synthesize research findings [27]. The synthesis used in this article demonstrates the above that multiple sources were combined to form one article. The critical aspects when synthesizing written information from various sources or literature is to take a step further and go beyond merely summarizing the articles read [26]. This article draws from multiple sources which include feminism, decolonization, Freirean approaches, indigenous feminism, Africana womanism, Ubuntu as well as effective leadership. The discussion starts by examining indigenous feminism, society and liberatory values.

\section{Women and Liberatory Values}

Gearon [28] affirms that there must be a call to bring back matriarchy in indigenous communities in order to rebuild and decolonize community life. Gearon [28] adds that indigenous feminism can transform our world and have more people finding meaning in words such as matriarch or matriarch-in-training. When people become aware of such concepts, they have moved towards decolonizing, which is about recognizing, naming and discarding the forced worldview imposed by colonialism [28]. Countless indigenous cultures have subsisted over decades sustained by indigeneity. Gearon [28] underscores the role of matriarchs in building and sustaining culture:

Most importantly, our feminism remembers and can call upon a history in which our matriarchal systems-something mainstream feminism hasn't yet achieved - not only actually existed but were practiced as essential aspects of our cultures. In some cases, this was just a few generations ago. Our cultures have survived in large part due to the strength of indigenous women, and women continue to lead today, despite not receiving credit or support.

The call to decolonize and indigenize society will come to fruition when the matriarchs are ready and empowered to transform society where the norm has always been determined by forced social systems. Arvin, Tuck and Morrill [29] argue that decolonized feminism should challenge heteropatriarchy and heteropaternalism in addition to race and class. On the one hand, heteropatriarchy refers to social systems where heterosexuality and patriarchy are perceived as normal and other constructions as aberrant. On the other hand, heteropaternalism means the presumption that heteropartriarchal nuclear-domestic arrangement where the father is the center is an acceptable model of society [29], [30]. Women should oppose oppressive practices as they strive for more freedom, thus embracing liberatory values. In addition, copious authors have argued that society needs relevant and revolutionary women's studies in society [31], [32], [33], [34].

Schniedewind [31] argues that any women's studies need relevant courses that analyze:

(a) The portrayal of women in traditional discipline;

(b) The ways in which women are oppressed and alternatives for their liberation; and 
(c) How the personal oppression of women is tied to the political, economic and social structure of society.

The focus of this article is on how women can use African philosophies to develop excellence in leading institutions. The Freirean approach to feminism embraces the liberatory methodology needed by women who want to build egalitarianist values based on community, social justice, epistemic freedom and equality. Schniedewind [31] points out that liberatory feminist values seek to replace hierarchical authority with participatory decision-making. "This does not imply structurelessness, but structure that is democratic. In the class, it is possible for a teacher to share leadership with both students and other instructors." How are these translated to indigenous knowledge? Sandell [35] points out that liberating feminist pedagogy should address the need for social change and focus on educating the oppressed "through strategies for empowering self, building community, and ultimately developing leadership." Feminist pedagogy will support the transformation of society through empowerment and leadership. Writing about education of the oppressed Freire [36] states that feminist pedagogy declares that everyone has a role to play and it fosters self-knowledge. Feminist pedagogy can be the starting point for women to understand themselves as leaders, as mothers, as community members and as purveyors of African values and indigenous feminism.

In support of African values among African women, Nnaemeka [37] claims that African feminism is proactive and rooted in the African environment. Furthermore, Nnaemeka [37] contends that "African feminist theory should be built on the indigenous in the same way that Claude Ake argues that for development to make some progress in Africa, greater attention must be paid to "building on the indigenous". In addition, Nnaemeka [37] claims that when we develop theory for women, we need to think of the concept 'nego-feminism', which implies two aspects or meanings. Firstly, nego-feminism refers to feminism of negotiation and, secondly, it refers to a 'no ego' feminism. Both are based on the communalism of many African societies. Unlike much of Western literature and Western feminists who only perceive feminism as a reaction to patriarchy, Nnaemeka [37] demonstrates its dynamism and goes beyond the simplistic definitions. The indigenous in Africa install feminism and African women are embedded in indigenous feminism. Furthermore, feminism in Africa is altruistic. For African women, feminism is what they do for themselves and their community. Kolawole [38] highlights the need for the reawakening of the African women's visibility and audibility. Moreover, Kolawole [38] points out that colonialism and patriarchy have silenced the African women.

Bell Hooks [39] defines the world we live in as a world in crisis. It is governed by politics of domination where the superior rules over the inferior. Furthermore, several feminist thinkers oftentimes cite sexual politics as the origin of this crisis. Yet, Paulo Freire's epistemology is a theory based on liberatory change in society, an epistemology that opposes domination. Usually, patriarchy is viewed as a hindrance to women's ascendance in society. The assumption from this point is that if sexist oppression and domination are eliminated, all forms of domination in society will be eliminated [39]. Additionally, Hooks [39] argues how Western white women tend to maintain that the feminist movement should be the central political agenda of women universally. Yet Hooks [39] affirms that this is flawed because it may imply among others that it is more legitimate to resist patriarchy than racism and other forms of social injustice.

Black women's leadership has grown within these contradictions and dynamics. Some feminist paradigms have magnified the schism between men and women as women are victims and men the enemy. So strong such paradigms have been that the drivers forget about other ills such as colonialism and apartheid influences. Hooks [39] warns that women should be aware of these truths or else they will be complicit in promoting false consciousness and fail to transform society. The sole focus on patriarchal domination obscures reality. When we look at the growth of women's leadership as a field, we see some of these realities. Women's leadership as a field has grown all over the world and black women in South Africa, like others on the continent and in the world, have had to explore race and gender in the workplace. Others have seen the presence of women in leadership positions as a quest for social justice leadership and equality. The challenge when discussing women's leadership is to regard the women's experience as homogenous and pointing to patriarchy as the main culprit that thwarts women's development. The latter may be the reason that society thinks that it advances the cause of women because they paradoxically support the status quo. The next section explicates the concept linked to these debates and this is Africana womanism.

\section{Africana Womanism}

In the late 1980s, Hudson-Weems [40] coined the term 'Africana womanism' that includes all women of African descent. The concept reflects African culture and highlights the struggles of women. Hudson-Weems [40] points out that Africana womanism is very different from feminism or Alice Walker's feminism. Furthermore, Hudson-Weems [40] explains that Africana womanism is built on eighteen key components namely, Self-naming, Self-definition, Family-centeredness, Wholeness, Role flexibility, Adaptability, Authenticity, Black female sisterhood, Struggling with males against oppression, Male compatibility, Recognition, Ambition, Nurturing, 
Strengthen, Respect, Respect for elders, Mothering and Spirituality [41]. All these demonstrate the broad roles played by women within and outside the home. Some show the ability of women to unify society through their capability of being leaders. Most importantly, these components reflect the Pan Africanist lens, which uncovers the kindred spirit that exists between black women and their communities.

In Africana womanism, racism is a priority over sexism although sexism emanates from racism, classism and economic prejudices [42]. Women should uplift the role and dignity of women in society as they oppose white organizations. Yet, Hudson-Weems [43] also states that Africana women encounter problems in life perpetrated inside and outside their race. These challenges include sexual harassment and physical abuse and all should be solved in Africana communities. Africana womanists have serious problems with the concepts 'black feminism' and 'African feminism' because they are on the other side of the same coin of feminism or, to be precise, Eurocentric or Western feminism. Therefore, Africana feminism is not the same as black feminism. Ntiri-Williams [42] declares:

According to Hudson-Weems, "feminism was conceptualized and adopted by white women, reflecting an agenda which was designed to meet their particular needs." She concludes, therefore, that Black or African feminism that originates from mainstream feminist theory is in a sense a postscript or after-thought, and therefore "extremely problematic as labels for the true Africana woman." Africana Womanism and its agenda are unique and separate from both White feminism and Black feminism.

Barry and Grady [44] refer to Africana womanism as an extension of feminism to account for a distinctively Africana perspective. Barry and Grady [44] argue that there is a need to acknowledge the exclusive gender roles in countries of the Global South. These writers maintain that society needs to delineate gender dynamics before colonialism. Barry and Grady [44] highlight gender dynamics in precolonial Sub-Saharan Africa and find Africana womanism as one of the most crucial. Furthermore, Barry and Grady [44] argue that in times of strife and hostility countless Africana women will underscore racism before individual needs and other colonial and patriarchal concepts.

Barry and Grady [44] argue that it should be plausible to start at Africana womanism when examining feminism. Africana womanism deals with the experiences that bind all Africana women and in this very way Africana womanism seeks to unify black women all over the world. Therefore, Africana womanism is a synonymous call to global unity among all black women [44]. Race is critical in Africana womanism and Barry and Grady [44] point out that Africana women are marginalized because of their race, socio-economic condition and gender.
Furthermore, Africana womanism distinguishes itself from feminism. "The racial and gender antagonisms of white women are disclaimed by black women who reject being inferior to the white race and consider their men as an integral part in their struggle to dismantle the shackles of enslavement, marginalization and poverty" [45]. Ebunoluva [46] spells out that feminism as portrayed by white feminists excluded black women from participating fully in the movement. Africana womanism maintains that women's liberation can only be achieved when the entire race is freed and hence a partnership exists between men and women in that struggle. Therefore, womanism differs from feminism because it acknowledges the triple oppression of black women, which are race, class and sexism. Feminism's main obsession is sexism and not race and class [46]. The latter is a problem presented by the Eurocentric view, as it wants to eclipse the Afrocentric position. Yet Sofola [47] states that the Eurocentric view of feminism seeks to dewomanize the African woman because the Eurocentric definition of woman is alien and destructive to the African of African heritage [43]. Another theory that has enabled scholars to examine gender, social power and colonialism has been the theory of subaltern.

The concept of subaltern is used when referring to women. Ismail and Konta [48] cite Ghazoul who describes the concept as referring to that which is below everything else. Walia [49] argues that gendered subaltern means that women have been doubly subalternized; on the one hand, they are demeaned because of their nationality whilst on the other hand, they have been subalternized based on gender. Spivak was able to gender the subaltern by combining gender, class and race, because these are inseparable, and people need to see them differently from Western feminist lens. As discussions above demonstrate, women have been treated as "the other", "the colonized" deprived and having suffered under oppression and repression [49]. Adapted by Antonio Gramsci, the concept of subaltern encompasses groups that are dominated by the ruling classes. When people speak of "gendered subaltern", they refer to the dominance exerted by society which led to women's marginalization. Class, caste, race and gender are among the factors society uses to justify women's marginalization and oppression. This marginalization and oppression lead to gender and women's invisibility, which was briefly discussed in the opening paragraph. Gender subalternity enables society to understand not only women's history but social justice principles as well. Activist women would seek to find and raise their voice against dominant, colonial and repressive hegemony. Womanism and indigenous feminism are among approaches that strive towards giving women a voice to be able to resist the status quo that seeks to subjugate women.

Below, the focus is on the philosophy of Ubuntu and how it can help advance indigenous feminism as well as women's leadership. 


\section{Ubuntu, Indigenous Feminism and Effective Leadership}

Poltera [3] points out that the concept of "woman leadership" cannot be trivialized. Poltera [3] also refers to women's leadership in African contexts as an umbrella concept which refers to individual and collective leadership portrayed by African women on the African continent. Women's leadership is also critical in the context of South Africa because it seeks not only to promote women's rights but seeks to redress inequalities, empower women and uphold equity [3]. As evident in the discussions above, researchers around the world have highlighted how women's leadership prowess is thwarted by societal barriers [50]. Yet there is a realization that women bring transformative leadership which is perceived as essential to the building and sustenance of resilient and responsive workplaces [51].

The question many may ask is how philosophies such as Ubuntu are linked to indigenous feminism. In a 2008 study, Msila [52] traces the effectiveness of a black woman school principal who utilized the Ubuntu worldview to lead her school to better performance and instil good followership. Msila [52] points out that the principal used common vision and participative strategies embedded in caring, sharing, respect and compassion. Ubuntu is an African worldview which reflects African humanness imbedded within the Ubuntu philosophy. This worldview is about dependability, community, solidarity and social justice. Several authors have demonstrated how some qualities such as solidarity, compassion, tolerance and empathy are part of this worldview [53], [54], [55], [56]. Furthermore, Hudson-Weems [43] refers to Ubuntu philosophy as that which contains life-coping skills from Africa and states that there are several values contained within it, these include humanness, caring, sharing, respect, compassion and self-motivation. Additionally, Broodryk [55] portrays the Ubuntu personality as a human being who embodies the ancient Ubuntu values. The Ubuntu personality promotes the values of the community rather than the individual. The Ubuntu personality is against conflict, hatred and numerous other ills. Furthermore, it seeks progress and advancement for all and its ideals are best expressed in the maxim, "I am because you are". Broodryk [55] adds that the Ubuntu personality possesses critical skills, and these skills include togetherness, equality, sharing, sympathy, happiness, empathy, tolerance and harmony.

Cornell and Van Merle [57] write about what they refer to as Ubuntu feminism, which is a form that responds to Western feminism. This feminism promotes interconnectedness and answers the question of what it means to be a human being who lives among others. Furthermore, Cornell and Van Merle [57] argue how Ubuntu can help in the fight against anti-black racism. I also believe that Ubuntu can restore the self-worth of women. Much research tends to make society believe in the warmth, motherhood, transformative and consultative qualities that women have. These are usually attributed to women as qualities unique to women leaders. This misleads because it means men are the opposite and are prone to be more successful because men are more focused on production hence, they may be "cold" and decisive. As a result, some literature has shown how many women may try to emulate men's leadership styles because these are perceived as relevant to the progress of the organization. Arguably, Ubuntu is a worldview that is gender neutral - it emboldens women's role in society because it makes us see women as human beings who are playing a role in enhancing community ideals. Gender stereotyping, including patriarchy, racial oppression, and class distinctions, is opposed by the Ubuntu worldview. It is critical for women using Ubuntu philosophy to be conscious and be able to:

- Oppose the demands of patriarchy;

- Oppose colonial views on gender;

- Enhance qualities that build communities and organizations; and

- Embrace African values that promote dependability and equality.

Ubuntu philosophy shows that gender inequality can be addressed in all traditional societies. Afisi [58] argues that indigenous people in Africa performed varying roles in society to ensure the efficiency of society prior to the advent of colonialism. The women and men's roles were complementary although there was the existence of the system where men were the heads of the families. This implies that traditional Africa was not based on gender inequality "but a complement of gender, because each gender has a role to play in contributions to societal development" [59].

However, there are feminists who have argued that Ubuntu is oppressive for women and very patriarchal [47], [48]. Shung-King et al. [51] points out that although Ubuntu is liberatory, it is male dominated and tends to ignore gender. However, many who may doubt Ubuntu may be applying Ubuntu within the realm of post-colonial environment where colonial cultures have contaminated traditional cultures and values. Arvin, Tuck and Morrill [29] contend that for African feminism to work, activists need to know, "when, where and how to detonate and go around patriarchal landmines." Ubuntu should be understood as a concept that seeks to dispel the myths of western feminists who draw on enmity between men and women. Nkealah [52] claims that feminism has been perceived as a movement that is anti-male and anti-culture. Yet the struggle for male-female equality is a struggle of both genders. The qualities of solidarity, communalism and dependability in Ubuntu enable empowered women to be able to collaborate with men in institutions and families through Ubuntu. Kolawole [50] points out that collaboration between men and women would exterminate women's oppression. Acholonu [19] uses the term 
motherism, which is made up of motherhood, nature and nurture qualities. A motherist can be a male or a female and the goal of a motherist is to continue with the human struggle. The male-female complementarity is critical in motherism because it ensures the totality of human existence. Ubuntu reflects these qualities. A woman leader using Ubuntu will be able to develop them.

\section{Womanist Thought - Empowering the Woman Leader}

As is evident above, Schniedewind [31] has always underscored the transformative role of feminism in society. A female leader following the womanist theory will realize that black feminists committed to womanism are committed to the survival of both the male and female [53]. Furthermore, Woodley [53] points out that womanism reflects personal insights from a black female perspective and that black female educators perceive the following as the foundation of their practice:

(i) Womanism is a spiritual movement as well as a social movement;

(ii) Womanists are committed to the survival of black people; and

(iii) Black womanist theory places black women's lived experiences at the center of analysis.

All these are critical to leadership discussed above for womanism empowers black women in leadership positions. The fact that it embraces the survival of both men and women means that it will be invaluable for the growth of the organization. Furthermore, womanism portrays women leaders as accomplished activists who juggle with several roles. Effective women leaders will internalize the different roles and be able to enhance their leadership journeys. Ogunyemi [64] captures a useful definition of womanism in Africa when she points out that, "Black womanism is a philosophy that celebrates black roots, the ideals of black life, while giving a balanced presentation of black womanism."

Next to womanism as discussed above is indigenous feminism that is vital for black women. Hudson-Weems [6] uses the terms 'Africana feminism' and 'Black feminism' differently. Africana feminism is rooted in Africa and it rejects man as the enemy and the way in which the feminist approaches perceive men. For Hudson-Weems [6] Black feminism has its own contradictions because it is distinctly African American and is fundamentally western. Furthermore, Hudson-Weems [6] points out that black feminists need white feminists' approval and white feminists always relegate them to the margins. Africana feminism is rooted in African ideals and does not relent to feminist notions that tend to support white supremacy and notions.

Broodryk [55] argues that in cultivating strong indigenous women leaders, cultural, social and political factors that influence indigenous women education leaders should be emphasized. More decolonial research needs to be explored as society examines the role of indigenous leadership as this article has done by exploring Ubuntu. Indigenous leadership is mainly about exploring identity and social justice among indigenous communities. Broodryk [55] states that three aspects shape indigenous perspectives in the United States and these are cultural identity, community engagement and social responsibility, and leadership values.

In the discussion on Ubuntu above, we have seen the interconnectedness between womanism and cultural values represented by Ubuntu. Khoza [65] in his book Attuned Leadership explains that leaders are not just born to a role. Instead, they are born and then made and, most importantly, a leader who is not attuned to his followers soon becomes irrelevant and will fail. Values such as connectedness, compassion, empathy, integrity, humility, reasonableness and determination are key to attuned leadership [65]. Furthermore, according to Khoza [65] attuned leadership uses African humanism, which then becomes a yardstick for decolonized leadership models. He points out that African humanism or Ubuntu forms the basis of ethical leadership. The leader practising African humanism will be able to embrace progressive thought and action that upholds caring leadership.

Courageous and conscious leaders can uphold such values as they build trust, harmony and ethical leadership. Research needs to emphasize the voice of indigenous educational leaders. Broodryk [33] points out that scholarships on educational leadership need to include women's experiences and emphasizes that leadership is more distinctly tied to the community and family rather than the individual. Afisi [58] claims that women in Africa have played critical roles in the development of African societies and the survival of families depended on the stature of women. The application of Ubuntu leadership in organizations is appropriate when we read Afisi [58] who states that African women were transmitters of culture and values and were teachers who were responsible for instilling traditional values and knowledge in children. "Men were also essential in the transmission of knowledge to the youth because they had a different type of knowledge of the earth and environment, and also of ceremonies and traditions that were performed exclusively by men" [58].

\section{Conclusions}

This conceptual article is useful in the development of indigenous feminism in African contexts. The literature explored reveals several factors when it comes to black women leaders in society. The article also demonstrates the importance of concepts that people need to be aware of when it comes to women's leadership in the African context, because the awareness of these concepts is the 
first step towards decolonization and women's freedom. Indigenous feminism, motherism and womanism are some of the concepts that ensure that women are not alienated by society. Women have a huge role to play in the fight against all forms of oppression. Indigenous feminism and womanism should form the basis of alternatives to Western feminism. This is not to say African feminists share all the aspects of their theory, but several ideas like the Ubuntu philosophy discussed here tend to cut across these theories. Critical in these theories is that African women are able to shirk the idea of veiled colonialism where Western feminism prescribes what it means to be a woman who is black and African. Therefore, apart from opposing patriarchy, black women have a history to address as women, i.e. colonial and apartheid histories. Women leaders in education should always be aware of blind spots in Western feminism to be able to fight for social justice for women and their communities. African philosophies confirm the unity and solidarity of communities and do not emphasize the binaries of Western scholarship.

The article also examined the various reasons society needs to rethink leadership. Additionally, it shows why society should use diversity to stimulate transformation and improve organizations. The discussions above also illustrate why true women's leadership should support not only equity and equality but social justice as well. The struggle for women's rights is a struggle for a fair society based on women's inclusion and freedom. The debates also reflected that society needs to embrace new values opposed to colonialism and Western hegemony.

Finally, the article investigated the role of society in transforming women's leadership. The discussions also underscored the role of liberatory methodologies in freeing women and ways in which women should be ready to be empowered to transform society. Furthermore, black women can overcome race, class, power and gender biases in society. Yet, African societies should continue to oppose all obstacles that may hinder women leaders' proliferation. Successful women leaders will be nego-feminists who practice liberatory strategies to display womanism embraced by indigenous feminism. Finally, strong women should always be conscious about how they can be agents of social transformation through their roles in society. They need to be intentional in their roles to change society because colonialism and apartheid were methodical in entrenching social injustices.

\section{REFERENCES}

[1] Phakeng M, "Leadership: The Invisibility of African Women and the Masculinity of Power," South African Journal of Science, vol 111 no. 11/12, 2015. http:// dx.doi.org/10.17159/sajs.2015/a0126

[2] Ilesanmi O.O, "Women's Visibility in Decision-making
Processes in Africa - Progress, Challenges, and Way Forward," Frontiers in Sociology, December 2018. https://doi.org/10.3389/fsoc.2018.00038

[3] Poltera J, "Exploring Examples of Women's Leadership in African Contexts," Agenda, vol. 33, no. 1, pp. 3-8, 2019. https:// 10.1080/10130950.2019.1602977

[4] Sylvester, C, "African and Western Feminisms: World-Traveling the Tendencies and Possibilities," Signs, vol. 20, no.4, pp. 941-969, 1995.

[5] Oyewumi O, "The Invention of Women: Making an African Sense of Western Gender Discourse," University of Minnesota Press, 1997.

[6] Hudson-Weems C, "Africana Womanism: An Authentic Agenda of Africana Descent," Tri-State Defender Newsroom. 2001.

[7] Bayu EK, "A Comparative Analysis on the Perspectives of African Feminism Vs Western Feminism: Philosophical Debate with Their Criticism and its Implication for Women's Rights in Ethiopia Context," International Journal of Sociology and Anthropology, vol. 11, no. 4, pp. 54-58. 2019. https://10.5897/IJSA2018.0783

[8] Omotoso S.A, "New Media is Misrepresenting Women in Africa: What Feminists can do,'The Conversation, August 5, 2019.https://theconversation.com/new-media-is-misrepr esenting-women-in-africa-what-feminists-can-do-121128

[9] Lewis E.A, “A Literature Review of Black Women's Portrayal in Media and Its effects on their Treatment in Society," Hons diss. University of North Carolina, 2019.

[10] Lues, L. "The History of Professional African Women: A South African Perspective," Interdisciplinary Journal, 4(1): 103-123, 2005.

[11] Mayer, C.-H. “A 'Derailed' Agenda? Black Women's Voices on Workplace Transformation," Journal of International Women's Studies, 18(4), 144-163, 2017.

[12] Lugones, M, "Coloniality of Gender," World \& Knowledges Otherwise, Spring, pp. 1-17.

[13] Smith A, "Decolonizing Anti-Rape Law and Strategizing Accountability in Native American Communities," Social Justice, vol. 37, no. 4 pp. 36-43, 2011.

[14] Phillips L, “The Womanist Reader," Routledge.

[15] Brewer R.M, "Black Feminism. In Companion to Feminist Studies," edited by N.A. Naples. John Wiley Sons, 2021, pp. 91-104.

[16] Breines W, "What's Love Got to Do with It? White Women, Black Women, and Feminism in the Movement Years," Signs, vol. 27, no. 4, pp. 1095-1133. 2002. https://doi.org/10.1086/339634.

[17] Stanford Encyclopaedia of Philosophy. "Feminist Philosophy," 2018. https://plato.stanford.edu/entries/femin ist-philosophy (accessed July.6, 2021)

[18] De Beauvoir S, “The Second Sex,” Vintage Press. 1949.

[19] Liddle C, "Intersectionality and Indigenous Feminism: An Aboriginal Woman's Perspective," The Postcolonialist. 2014. https://za.pinterest.com/pin/688980442963140632/ (accessed July 16, 2021). 
[20] Moreton-Robinson, A. Talkin' up to the White Woman: Indigenous Women and Feminism. Brisbane, AU: University of Queensland Press. 2002.

[21] Acholonu O, C, "Motherism: The Afrocentric Alternative to Feminism," Afa Publications, 1995.

[22] Alkali M, Talif R, Yahya W, R, W, JM, Jan, "Dwelling or Duelling in Possibilities: How (Ir) relevant are African Feminisms?" GEMA Online Journal of Language Studies, vol. 13, no. 3, pp. 237- 253, 2013.

[23] Ogundipe-Leslie, M. "Re-creating Ourselves: African Women \& Critical Transformations," Africa World Press, 1994.

[24] Jaakkola, E. "Designing Conceptual Articles: Four Approaches," AMS Review, 10:18-26, 2020. https//: doi.org/10.1007/s13162-020-00161-0.

[25] Pound, P, R. Campbell, "Exploring the Feasibility of Theory Synthesis: A Worked Example in the Field of Health Related Risk-Taking," Social Science and Medicine, 124: 57-65, 2015. https://doi: 0.1016/j.socscimed.2014.11. 029.

[26] McCombes, S, "How to Synthesize Written Information from Multiple Sources. Simply Psychology, 2020. www.simplypsychology.org/synthesising.html

[27] Schick-Makaroff, K, McDonald, M, Plummer, M, Burgess, J, W. Neander, "What Sysnthesis Methodology Should I Use? A Review and Analysis of Approaches to Research Synthesis," AIMS Public Health, vol 3, no 1, pp. 172-215, 2016. https://10.3934/publichealth.2016.1.172.

[28] Gearon J, "Indigenous Feminism is our Culture. Stanford Social Innovation Review," 2021. https://ssir.org/articles/e ntry/indigenous_feminism_is_our_culture (June 10, 2021).

[29] Arvin M, Tuck E, A. Morrill, "Decolonizing Feminism: Challenging Connections between Settler Colonialism and Heteropatriarchy," Feminist Formations, vol. 25, no. 1, pp. 8-34, 2013.

[30] [30] Valdes, F, "Unpacking Hetero-Patriachy: Tracing the Conflation of Sex, Gender \& Sexual Orientation to its Origins," Yale Journal of Law \& The Humanities, vol. 8, pp 161-211.

[31] Schniedewind N, "Feminist Values: Guidelines for Teaching Methodology in Women's Studies," In Freire for the Classroom: A Sourcebook for Liberatory Teaching. Edited by I. Shor, Heinemann. 1987, pp. 170-179.

[32] Cole R. C, N.Z.Haniff, "Building a Home for Black Women's Studies." Black Women, Gender Families vol. 1, no. 1, pp. 24-45. 2007.http://www.jstor.org/stable/10.5406 /blacwomegendfami.1.1.0024.

[33] Ampofo A. A, Beoku-Betts, J, M.J. Osirim. "Researching African Women and Gender Studies: New Social Science Perspectives," African and Asian Studies, vol. 7 (2008), pp. 327-341.

[34] Crouch, B, "Finding a Voice in the Academy: The History of Women's Studies in Higher Education," The Vermont Connection, vol. 33, Article 3. 2012. https://scholarworks. uvm.edu/tvc/vol33/iss $1 / 3$

[35] Sandell, R, "The Liberating Relevance of Feminist
Pedagogy," Studies in Art Education: A Journal of Issues and Research, vol. 32, no. 3, pp. 178-187, 1991.

[36] Freire, P, "Pedagogy of the Oppressed," Continuum. 1970.

[37] Nnaemeka O," Nego-Feminism. Theorizing, Practising and Pruning Africa's Way," Signs: Journal of Woman in Culture and Society, vol. 29, no. 2, pp. 357-385, 2004.

[38] Kolawole M, "Womanism and African Consciousness," Africa World Press, 1997

[39] hooks Hooks b, "Feminism: A Transformational Politic. I Am Because We Are: Readings in Black Philosophy," edited by F.L. Hord \& J,. Scott Lee, University of Massachusetts Press, pp. 329-337 1995.

[40] Hudson-Weems C, “Africana Womanism: Reclaiming Ourselves," Bedford Publishing, 1998.

[41] Alexander-Floyd N.G, Smien EM, "Revisiting "What's in a Name?" Exploring the Countors of Africana Womanist Thought". Frontiers: A Journal of Women Studies, vol. 27, pp. 67-89. 2006. https://10.1353/fro.2006.0011

[42] Ntiri-Williams D, "Introduction'” in C Hudson- Weems Africana Womanism, Bedford Publishers, 1993.

[43] Hudson-Weems C, "Africana Womanism: An Overview," In Out of the revolution: Development of Africana Studies, edited by D.P. Aldridge, \& C Young, Lexington Books, pp. 205-217, 2000.

[44] Barry F, B, Grady S.C, "Africana Womanism as an Extension of Feminism in Political Ecology (of Health) Research," Geo Forum, vol. 103, pp. 182-186, 2019.

[45] Al-Harbi A.O, 'Africana Womanist Perspectives in Reading Dangaremga's Nervous Conditions," AWEJ, vol. 1, no. 4, pp. 119-128, 2017. http://dx.doi.org/10.24093/aw ejtls/vol1no4.9

[46] Ebunoluva S.M, "Feminism: The Quest for an African Variant," The Journal of Pan African Studies, vol. 3, no. 1, pp. 227-234, 2009.

[47] Sofola Z, "The Artist and the Tragedy of a Nation," University Press, 1994.

[48] Ismail, A, M, Konta,"Spivakon Representing Gender: Can Subaltern Women Speak? The Caravan, 13 May 2018, au ccaravan.com/?p=7322

[49] Walia, G, "The Theme of Gendered Subaltern in the Works of Mahasweta Devi." Research Scholar, vol 3, no.1, pp346 $-352,2015$.

[50] Alqahtani T, "Barriers to Women's Leadership," Granite Journal, vol. 3, no. 2, pp 34-41, 2019.

[51] Shung-King M, Gilson L, Mbachu C, Molyneux S, Muraya K.W, Uguru, N, V, Govender, "Leadership Experiences and Practices of South African Health Managers: What is the Influence of Gender? - A Qualitative, Exploratory Study," International Journal for Equity in Health, vol. 17, pp. 148, 2018. https://doi.org/10.1186/s12939-018-0859-0

[52] Msila V, "Ubuntu and School Leadership," Journal of Education, vol. 44, pp. 67-84, 2008.

[53] Mbigi L, "Ubuntu: The African Dream Management," Randburg: Knowledge Resources, 1997. 
[54] Mbigi L, "The Spirit of African Leadership," Knowledge Resources, 2004

[55] Broodryk J, "Ubuntu: Life-coping Skills from Africa," Knowledge Resources, 2006.

[56] Msila V. "Ubuntu; Shaping the Workplace with (African) Wisdom,” Knowledge Resources, 2015.

[57] Cornell D, Van Marle K. "Ubuntu Feminism: Tentative Reflections," Verbum Eccles, vol. 36, no. 2, pp. 1-18. 2015. http://dx.doi.org/10.4102/VE.V36I2.1444

[58] Afisi O.T, "Power and Womanhood in Africa: An Introductory Evaluation," Journal of Pan African Studies, vol. 3, no. 6, pp. 229-238, 2010.

[59] Okome M. O, "What Women, Whose Development? A Critical Analysis of Reformist Evangelism on African Women," In African Women and Feminism: Reflecting on the Politics of Sisterhood edited by O. Oyewumi, African World, 2003. pp. 67-98.

[60] Kolawole M.M, "Reconceptualizing African Gender Theory: Feminism, Womanism and the Arere Metaphor,"
In Rethinking Sexuality in Africa, edited by S. Arnfred, Nordiska Afrikainsitutet, 2004.

[61] Manyonganise M. "Oppressive and Liberative: A Zimbabwean Women's Reflections on Ubuntu," Verbum Et Ecclesia, vol. 36, no. 2, pp. 1-7, 2015 http://dx.doi.org/10.4102/VE.V36I2.1438

[62] Nkealah N.N, 'Conceptualizing feminism(s) in Africa: The Challenges Facing African Women Writers and Critics," English Academy Review, vol. 23, no. 1, pp. 133-141. 2006. https://doi.org/10.1080/10131750608540431

[63] Woodley X. Black Womanist Leadership: Lessons Learned. 2015. http://ywca-nm.org/black-womanist-leadership-lessons-lea rned/ (accessed May 2, 2021).

[64] Ogunyemi C, "Womanism: The Dynamics of the Contemporary Black Female Novel in English," Journal of Women in Culture and Society, vol. 11, no. 1, pp.63-80, 1985.

[65] Khoza R.L, "Attuned Leadership: African Humanism as Compass," Penguin Global, 2012. 